UNRAM Law Review is licensed under a Creative Commons Attribution 4.0 International License, which permits unrestricted use, distribution, and reproduction in any medium, provided the original work is properly cited. p-ISSN: 2548-9267 | e-ISSN : 2549-2365, Open Access at : http://unramlawreview.unram.ac.id/index.php/ulr

\begin{tabular}{c|c|c|c|c|}
\hline Volume & Issue & Page & April & p-ISSN: 2548-9267 \\
\hline 4 & 1 & $54-63$ & 2020 & e-ISSN : 2549-2365
\end{tabular}

\title{
The Shift Paradigm of the Death Penalty in the Draft Criminal Code
}

\author{
Titin Nurfatlah \\ Program Studi Magister Ilmu Hukum Program Pascasarjana \\ Universitas Mataram \\ Email: titinnurfatlah11@gmail.com
}

Amiruddin

Fakultas Hukum

Universitas Mataram

Email: amiruddin.fh.unram@gmail.com

Ufran

Fakultas Hukum

Universitas Mataram

Email: ufrantrisa@yahoo.com

\begin{abstract}
This study aims to determine the concept of the death penalty in the future Indonesian criminal law. The method used is a normative research method. The approaches in this research are the statute approach, conceptual approach, historical approach, and comparative approach. The conclusion based on the results of the research, the death penalty in the Draft of the Penal Code is no longer a primary punishment but has separate rules. The provisions of the death penalty in the Draft Penal Code is particular and as an alternative punishment. The purpose of this death penalty provision includes giving broader consideration for judges in giving decisions as not arbitrary towards the convicted; give more attention to the objectives of the punishment. Additionally, the provision advocates the death penalty as a last resort in protecting the community, as the judges shall look for other punishment as an alternative to the death penalty. The Draft of the Criminal Code bases on Neo-Classical school of thought, which maintains a balance between objective factors (actions/outward) and subjective factors (people/ inner/inner attitudes).
\end{abstract}

Keywords: shift; paradigm; the death penalty.

\section{INTRODUCTION}

Death punishment is one of the sanctions in the criminal justice system perpetually coining controversy. After two and a half centuries of moral debate and four decades of constitutional argument, one thing that seems indisputable that the death penalty creates an endless stream of discourse. ${ }^{1}$ Pros and cons occur due to different points of view of each person regarding the death penalty. This debate has arisen in various countries in

1 David Garland.(2010).Peculiar Institution (America's Death Penalty In An Age Of Abolition). Cambridge, Mas sachusetts: The Belknap Press Of Harvard University Press, p. 9:"... after two and a half centuries of moral debate and four decades of constitutional argument, the one thing that seems in disputable is that the death penalty produces an endless stream of discourse." 
the world, including Indonesia. The death penalty has incorporated into national law through Law Number 1 of 1946 concerning Criminal Law Regulations as amended by Law Number 73 of 1958 concerning Declaring the Enactment of Law Number 1 of 1946 of the Republic of Indonesia concerning Criminal Law Regulations for All Regions Republic of Indonesia and Amend Criminal Law. Furthermore, the death penalty adopted in Article 10 of the Criminal Code as one of the severest principal punishment in force.

Recent development showed that the death penalty had abandoned by many countries in various parts of the world, and some others are maintained this punishment. Referred to the results of research conducted by several international institutions such as Amnesty International, it turns out that most countries still adhere to the death penalty in their Criminal Code. The regulation of the death penalty divided into several patterns. Some countries had abolished this punishment (abolitionists), such as Portugal, Denmark, Australia, New Zealand. On the contrary, various countries in other hemispheres maintaining capital punishment as one of the sanctions in the criminal justice system (retentionist), for example, Afghanistan, Algeria, Saudi Arabia, Thailand, and others. ${ }^{2}$ In the latest development, a new pole has emerged, namely the compromise pole, which occurs when the death penalty was executed or canceled due to other factors beyond the law, such as politics or economics.

The Netherlands, as the 'biological mother' of the Criminal Code, has long abolished it since 17 February 1983. The abolition of the death penalty in various countries has widely carried out; this is as Sajipto Raharjo's opinion, which states that: ${ }^{3}$

"The development of civilization leads us to a delicate civilization, especially when talking

about something related to humans. Many teachings, doctrines, institutions were created to protect human glory. Talking about capital punishment today cannot be done like we did talking about it a thousand years ago. "

In the past, when society accepts the adage of "life for life," there is not much debate concerning the death penalty. Endless discussions and study concerning the death penalty occur, notably when it clashed with human rights rules. Even though judges hardly imposed the death penalty, but the polemic on this matter usually arise whenever the court imposed this punishment, or on the execution of the court decision.

In Indonesia, the death penalty listed in the provisions of article 10 point (a) of the Criminal Code. The death penalty is placed as a principal criminal, along with imprisonment, confinement, fine, and closing. The Draft of Criminal Code in September 2019, which designed as a reform of the Indonesian criminal law, the death penalty is no longer made as a general principle punishment but put as a particular principal punishment. Politics of law is indeed inseparable from the construction of the desired future Indonesian criminal law based on the idea of mono-dualistic balance. Criminal law pays attention equally between the rights or interests of the wider community or the state (including victims) on one side, and the rights/ interests of individual perpetrators (offenders) as humans on the other side. ${ }^{4}$

The emergence of the death penalty in the Draft of Criminal Code is an endless debate. The existence of the death penalty in the Draft of Criminal Code with a "new face" that is as a particular principal punishment, and its implementation is as an alternative. This new face of the death penalty showed that there is displacement in the view of the criminal system, which no longer views criminal justice as a means of retaliation. The existence of the death penalty

2 Andi Hamzah.(2003).Pengkajian Hukuman Mati di Indonesia. Jakarta: BPHN Departemen Hukum dan HAM, p. 4-5.

3 Sajipto Raharjo.(2010). Sosiologi Hukum. Yogyakarta: Genta Publishing, p. 160.

4 Barda Nawawi Arief.(2004). "Pokok-Pokok Pemikiran (Ide Dasar) Asas-Asas Hukum Pidana Nasional, " Makalah dalam Seminar Nasional tentang Asas-Asas Hukum Pidana Nasional, Diselenggarakan oleh BPHN Departemen Ke hakiman dan HAM RI Jakarta bekerjasama dengan Fakultas Hukum UNDIP Semarang, 26-27 April 2004, p.17 
in the Draft Penal Code is like a "dubious middle way." The death penalty does not eliminate from the criminal justice system. However, its enforcement carried out more stringently so that it only applied to "human beings without forgiveness." Therefore there is a displacement paradigm in the death penalty in the Draft of Criminal Code. The drafters considered this new form of the death penalty as a middle ground between abolitionists and retentionists in the debate about the death penalty. This paradigm displacement is undoubtedly shall be sifted through, whether in the purpose of punishment using the retributive paradigm, restorative, or by using the paradigm of the goal of combined punishment. The most interesting thing is that the death penalty in the Penal Code as the severed criminal is still maintained.

Starting from the idea that the criminal law is a means to the purpose, the concept of the death penalty shall, first of all, formulates the goal of punishment. Barda Nawawi Arief argues that in identifying the purpose of punishment, the concept departs from the balance of two main objectives, namely "community protection" and the protection or coaching of individual criminal offenders. ${ }^{5}$ Therefore this study aims to analyze the concept of the death penalty in the future of Indonesian criminal law.

\section{METHOD}

The type of research of this legal writing is normative legal research, where Soemitro said that normative legal research is a literature (study). ${ }^{6}$ The approaches used in this study are a statute approach, a conceptual approach, a comparative approach, and historical approach. In this study, the authors use secondary data (secondary data), in which Amiruddin and H. Zainal Asikin stated that "for normative legal research that only recognizes secondary data, which consists of primary legal material, secondary legal material, and tertiary legal material."

Primary legal materials used are the 1945 Constitution of the Republic of Indonesia, the Criminal Code (KUHP) as stipulated under Law Number 1 of 1946 in conjunction with Act Number 73 of 1958, Law Number 5 ( PNPS) 1959 On The Authority of the Attorney General, Law Number 21 of 1959 On Aggravate the Sentences of Economic Crimes, Emergency Law Number 12 of 1951 On Firearms, Ammunition or Explosive Substance, Law Number 11 (PNPS) of 1963 concerning Eradication of Subversion Activities, Law Number 31 of 1964 On Basic Provisions for Atomic Energy, Law Number 5 of 1997 On Psycho tropics, Law Number 4 of 1974 On Aviation Crimes and Crimes against Aviation Facilities/Infrastructure, Law Number 35 of 2009 On Narcotics, Law Number 31 of 1999 On Corruption Eradication, Law Number 26 of 2000 On Human Rights Courts, Law Number 15 of 2003 On Eradication of Terrorism Crimes, and Law Number 35 of 2014 On Amendments to Law Number 23 of 2002 concerning Child Protection.

The secondary legal materials are the draft of the Penal Code and research results. The tertiary legal material used in this legal research is the legal dictionary. The technique of collecting legal material is the study of literature, which is the collection of legal material by reading the legislation, official documents, journals, articles from the internet, as well as other literatures that are closely related to the issues discussed. Legal materials collected then analyzed using deductive thinking and comparative thinking. Deductive way of thinking conducted by stand with abstract matter applied to concrete propositions. This way of thingking applies through

5 Barda Nawawi Arief.(2008). Bunga Rampai Kebijakan Hukum Pidana:Perkembangan Penyusunan Konsep KUHP Baru.Cet.5. Jakarta: Prenadamedia Group, p. 97.

6 Soemitro, Rinny Hanitijo.(1990) .Metodologi Penenlitian Hukum dan Jurimetri. Jakarta: GhaliaIndonesia, , p.11.

7 Amiruddin dan Zainal Asikin. (2016). Pengantar Metode Penelitian Hukum. Cet. 6. Jakarta: PT. Rajagrafindo Persada, p.163. 
operationalizing theories of criminal law in the event of the death penalty in Indonesia. The comparative method impose by contrasting norms with the phenomenon of the death penalty.

\section{ANALYSIS AND DISCUSSION}

\section{The Death Penalty in Indonesian Positive Law}

The death penalty in Indonesia have existed before the arrival of the Dutch; this is evident from the existing customary law in some areas. Based on history, it turns out that the death penalty was known long before the Indonesian state was formed, namely in the period of monarchy. For example, the kingdom of Kutai Kartanegara ${ }^{8}$ is based on the Selaten Penal Law and in the Majapahit Law that stipulates the death penalty as the primary punishment. Indonesia still enacted the death penalty as a form of punishment in the positive law. Therefore, the death penalty is a form of punishment which is still legally carried out in this country. The death penalty stipulates as the punishment for certain crimes as regulated in the Criminal Code, as well as those outside the Criminal Code (Special Law). In the Criminal Code, the provisions of the death penalty stated in Article 10 of the Criminal Code, which defines the death penalty is part of the primary punishment. Prof. Roeslan Saleh, in his book Indonesian Criminal Stelsel confirmed that the Indonesian Penal Code limits the possibility of imposing the death penalty for some serious crimes. For more details, these qualifications described in the following table:

Table 1. Crimes Punished by Death Penalty in The Criminal Code.

\begin{tabular}{|c|c|c|}
\hline Number & Crimes & Articles in The Criminal Code \\
\hline 1 & State Security Disturbance & $104,111(2), 124(3)$ \\
\hline 2 & Treason against Head of State Ally & $140(3)$ \\
\hline 3 & Premeditated murder & 340 \\
\hline 4 & Crimes Against Property & $365(4), 368(2)$ \\
\hline 5 & Crimes Against Navigation & 444 \\
\hline 6 & Aviation Crimes & $479 \mathrm{k}(2), 479 \mathrm{k}(2)$ \\
\hline
\end{tabular}

Data Source: processed from The Criminal Code

Based on the table above, there are six types of crimes sentenced with the death penalty in the Criminal Code, which include ten articles. Three articles relating to disturbance in state security, one article about treason against heads of state ally, one article on premeditated murder, two articles on crimes against property, one article on crimes against navigation, and two articles on crimes on aviation. Reviewed the contents of the ten articles, it appears that the death penalty is an alternative form. It implies that the Judges may sentence the perpetrators of the crimes mentioned therein to life imprisonment or imprisonment of up to twenty years.

Several laws have regulated by the Indonesian Parliament and the President of the Republic of Indonesia (RI) stipulate particular crimes sentenced with the death penalty. Those crimes and the regulation presented in the table below:

\begin{tabular}{|c|c|c|}
\hline Number & Act & Articles \\
\hline 1 & $\begin{array}{r}\text { Law Number } 35 \text { Year } 2009 \text { Concerning Narcot- } \\
\text { ics }\end{array}$ & $\begin{array}{r}\text { Article } 113(2), \text { Article } 114 \\
\text { (2), Article } 116(2), \text { Article } \\
118(2), \text { Article } 119(2), \\
121(2), \text { and } 133(1)\end{array}$ \\
\hline
\end{tabular}

8 http://www.kerajaannusantara.com/id/kutai-kartanegara/hukum/, downloaded at 11 Maret 2020. See also Slamet Muly ana, Prundang-undangan Majapahit, Jakarta: Bhrata, 1967 as cited by Andi Hamzah dan Andi Sumanglipu, (1984). Pidana Mati di Indonesia:Di Masa Lalu, Kini dan Masa Depan. Cet.I. Jakarta, p. 59. 


\begin{tabular}{|c|c|c|}
\hline 2 & & Article 59 (2) \\
\hline & $\begin{array}{r}\text { Law Number } 20 \text { Year } 2001 \text { Concerning Amand- } \\
\text { ment to Law Number } 31 \text { Year } 1999 \text { On } \\
\text { Corruption Eradication }\end{array}$ & Article $2(2)$ \\
\hline 4 & $\begin{array}{r}\text { Law Number } 26 \text { Year } 2000 \text { Concerning Court } \\
\text { of Human Rights }\end{array}$ & Article 36 and Article 37 \\
\hline 5 & $\begin{array}{r}\text { Law Number } 15 \text { Year } 2003 \text { on the Order of } \\
\text { Government Regulation in Lieu of Act } \\
\text { Number } 1 \text { Year } 2002 \text { On The Eradication of } \\
\text { Terorism Crimes Into a Law }\end{array}$ & $\begin{array}{r}\text { Article } 6,8,9,10 \text {, and Article } \\
14\end{array}$ \\
\hline 6 & $\begin{array}{l}\text { Law Number } 17 \text { Year } 2016 \text { On the Order of Gov- } \\
\text { ernment Regulation in Lieu of Act Number } 1 \\
\text { Year } 2016 \text { on The Second Amandment of Law } \\
\text { Number } 23 \text { Year } 2002 \text { On the Children Protec- } \\
\text { tion Into a Law }\end{array}$ & Article 81 (5) \\
\hline 7 & $\begin{array}{l}\text { Emergency Law Number } 12 \text { Year } 1952 \text { On the } \\
\text { Fire Arm, Ammunitions or Explosive Sub- } \\
\text { stance }\end{array}$ & Article 1 (1) \\
\hline 8 & $\begin{array}{r}\text { Government Regulation in Lieu of Act Number } \\
21 \text { Year } 1959 \text { On the Aggravates of Punish- } \\
\text { ment against Economic Crime }\end{array}$ & Article 1(2) \\
\hline
\end{tabular}

Data Source: processed from The Criminal Code

Based on the table, there are eight Indonesian laws whose articles contain sentences of the death penalty for perpetrators of crimes that are considered very dangerous for the security and order of the people, nation, and state. Indonesia still maintains the death penalty even though the Netherlands itself has abolished. As regards with this matter, the writer agree with H.J. Smidt, as quoted by Andi Hamzah in his book, explained that Indonesia is a large area with ethnic groups diversity where various influences cause tensions and lack of facilities on the police and the government, therefore capital punishment is still needed. ${ }^{9}$ Meanwhile, when viewed from the paradigm of the death penalty, this punishment directed to the retributive paradigm.

\section{Concept of the Death Penalty in the Future Indonesian Law}

Criminal and punishment in humankind history continually facing changes corresponding with the development of human civilization. The development of the formulation of criminal sanctions (criminal) in several countries, especially in Western Europe, has more advanced compared with the types of criminal law stipulated in the Indonesian Criminal Code. To pursue the remain criminal law from the development of society and the increasingly sophisticated technology, there is a change in criminal law, especially regarding the rapidly developing system of sanctions.

9 Andi Hamzah dan A. Sumangelipu. (1984). Pidana Mati Di Indonesia Di Masa Lalu, Kini dan Di Masa Depan. Jakart: Ghalia Indonesia, p. 25. 
Some countries make a total revision of the Criminal Code, such as Germany, Austria (1975), and the PRC (1980). Some continuously insert and revoke specific articles, such as the Netherlands, which almost every year makes changes to the Criminal Code (the latest amendment to the Dutch Penal Code in 2014). ${ }^{10}$ Indonesia is one of the countries that sluggish in enacting an amendment to the Criminal Code. Although the criminal law scholar has long begun to draft a Penal Code that is adapted to the philosophy of Pancasila, until the drafter has changed generations, however, the draft Penal Code seems not yet enacted based on various considerations.

The existence of the death penalty in the draft Criminal Code raises an endless polemic. The emergence of pros and cons views is inseparable as part of the existing social reaction. Generally, the pro-death sentence view or in this paper, the authors call it the term retentionist argues that capital punishment is quite effective in making deterrence or detachment (effect deterrent) for extraordinary acts. Meanwhile, the contra view of the death penalty or abolitionists generally holds that this punishment always attributes to human rights, which viewed the death penalty is a cruel and inhuman act.

Article 64 paragraph I of the Draft Penal Code stipulates that the criminal charge consists of the primary criminal charge, additional criminal charge, and specific criminal charge to a particular criminal offense defined in the law. Then, in the provision of Article 65 paragraph (1), it is determined that the primary criminal charge, as referred to in Article 64 letter (a) consist of imprisonment, closing penalties, criminal supervision, criminal penalties, and criminal social work.

Meanwhile, the death penalty individually regulated in the provisions of Article 67, which stipulates that the specific criminal charge as referred to in Article 64 letter (c), is the death penalty that always as an alternative punishment. Elucidation of Article 67 states:

"The death penalty stipulated in a separate article to show that this type of criminal charge has a specific nature. Compared with other types of criminal charges, the death penalty is the most severe type of crime. Therefore, it must always be an alternative for other types of criminal charge, namely life imprisonment or imprisonment for a maximum of 20 (years). “

The general explanation of the draft criminal code states that the death penalty does not listed with other criminal charges. The death penalty is determined in a separate article to show that this type of criminal charge is an exception. The type of the death penalty is the most severe and shall always sentenced alternatively to life imprisonment or imprisonment for a maximum of 20 (twenty) years. The death penalty can also be sentenced on a conditional basis by providing a probation period. Within this period, the prisoner expected to improve themselves so that the death penalty does not need to execute.

The purpose of the article is that the death penalty may impose as a punishment. However, its special nature implies that this punishment only to certain crimes; also, the specificity of this criminal charge means that the death penalty is not part of the general punishment but as a last resort in countermeasures crime. The death penalty, as regulated in Article 67 of the Draft Criminal Code, is no longer a primary punishment but stipulate individually, separate from the provisions of the primary criminal charge. Therefore Judges in sentenced criminal charge must highly cautious and rather selective. As emphasized by Barda Nawawi Arief, ${ }^{11}$ who stated that the judge's attitude in the determination of crimes and impose criminal charge must rather selective and prioritizing the prudential principle under the purpose of punishment in the Draft Criminal Code.

10 Andi Hamzah.(1993). Sistem Pidana dan Pemidanaan Indonesia. Jakarta: Pradnya Paramita, p. 17.

11 Barda Nawai Arief.(2010). Kebiajakan Hukum Pidana, Jakarta :Kencana Prenada Media Group, hlm. 90. 
The provisions of the death penalty are specific and alternative rules in the Draft Criminal Code is in line with provisions of Article 54 of the Draft Criminal Code that determines the following:

(1) In the punishment, it is obligatory to consider:

a. Form of wrongdoing of criminal offenses;

b. Motive and objective of committing a crime;

c. The mental state of the perpetrators of crime;

d. Whether the criminal acts premeditated or not premeditated;

e. Method to commit a crime;

f. The attitudes and conducts of the perpetrators after committing a crime;

g. Curriculum vitae, social and economic circumstances of the criminal offender;

$h$. The effect of a criminal offense on the future of the perpetrators of a criminal offense;

i. The effect of a criminal offense on the victim or the victim's family;

j. Forgiveness of the victim and/or his family;

$\mathrm{k}$. The value of law and justice that lives in society.

The phrase "mandatory" above explains that the nature of prudence in imposing penalties, including capital punishment, judges shall having regard to this article by considering social, moral, and rules aspects. The judge's selective attitude in placing the death penalty as an alternative criminal charge also emphasized in Article 57 of the Draft Penal Code. The article stipulates that in situations that a criminal act charges with the principal crime in an alternative manner, the imposition of a lighter primary crime must prioritize if only it considered be appropriate and able to support the achievement of punishment purpose.

The conclusion from some of the provisions above that Article 67 of the Draft Criminal Code strengthened with other articles relating to the objective of criminal punishment and the obligation of judges to the sentenced criminal charge. According to the writer's opinion, this is necessary so that the position of the death penalty as a specific and alternative criminal charge can apply well in the future, if indeed, the death penalty must be maintained in the Indonesian criminal system in the future.

In the academic text related to capital punishment, stressed that the effort to stipulate the death penalty separately from the primary criminal charge package is propitious, because it is a compromise as a way out among the retentionists. This arrangement implies that the death penalty is an exemption. Judges must give solemn and prudent ruling before imposing the death penalty. The debate about the death penalty remains a "live issue" everywhere and usually commonly revolves around reasons base on criteria:

a. community protection and criminal law enforcement systems

b. crime prevention

c. discriminatory and cruel natured

d. lower cost

e. retributive nature

f. public opinion pros and cons of the death penalty and the death penalty cannot be changed.

g. the shift in the paradigm of punishment in the Draft Penal Code

The purpose of criminal charge influenced by the philosophy used as the basis of the threatening and conviction. The Criminal philosophy is closely related to the justification of the existence of a criminal charge (whether the punishment as a retaliation, utility, and purposeful retaliation). The criminal philosophy is a philosophical basis for formulating a measure or basis for justice in the event of a violation of criminal law. There are two Philosophy of justice in 
criminal law that has strong influence, ${ }^{12}$ namely justice based on the philosophy of retribution (retributive justice) and justice based on the philosophy of restoration or restorative justice. The Criminal Code in force in Indonesia still adheres to the philosophy of justice, which is more inclined to retributive justice.

According to Eva Achjani Zulfa in her writings stated that: ${ }^{13}$

"This reality is not easy to understand because the meaning of justice that is closely related to the philosophy of punishment that has embedded in the minds of legislators and law enforcers refers to the paradigm of the objective of punishment in the form of retributive justice, which aims solely as retaliation. In this matter, the perpetrator is regarded as the object and acts passively toward the ongoing criminal process."

In reality, the interpretation of justice mentioned above has not satisfied several criminal law scholars. One of the criminal law scholars, Muzakkir, as quoted by Eva Achmad Zulfa ${ }^{14}$ in his dissertation, questioned the position of the victim of crime who never received attention in the criminal justice process. Another scholar, Made Dharma Weda, revealed that the enactment of a law is retroactively permissible as long as it benefits the victim. Refer to that two opinions, it can be seen until now, the concept of justice has not reflected the meaning of justice desired by the community, especially the victims.

Roeslan Saleh as quoted by Eva Achjani Zulfa confirmed that: ${ }^{15}$

"The concept of punishment purpose that developed so far is considered to have several weaknesses, mainly because it considered have no benefits whatsoever for victims and the community. This matter strengthened by the growth of public opinion about criminal law in various parts of the world. Criminal law is a juridical mirror that is most sensitive toward changes in culture, social conditions that are generally in all situations where humans exist.

Shift in a discourse on the death penalty influenced by three main factors, and those are; the development of human rights, changes in people's views of crime, and changes in people's views of the criminals. ${ }^{16}$ In this matter, the author agrees with Eva Achjani Zulfa's ideas, for example, in the case of human rights development factors, several countries concerning the death penalty ultimately choose to abolish capital punishment as one of the sanctions in their penal system. Such as France, which finally abolished the death penalty because it was considered a very cruel and inhuman sentence.

Criminal law primarily a reflection of the mindset of a society at a time. The contents of the rules contained in criminal law will depend on people's thoughts on a particular action. ${ }^{17}$ In the past, this change in thinking about crime seemed slow, so the demands on changing norms in criminal law did not confront problems. On the contrary, the current situation faced the challenge of chasing between developments that occur in society and legislation that tries to accommodate the needs of the changes.

In the draft Criminal Code, some provisions do not exist or never been regulated in the Penal Code of the Dutch Legacy (WvS) that are still in force today, one of which is the conditional death sentence. The death penalty in the Criminal Code that currently still in force is the embodiment of the criminal charge objective that leads to retribution (retributive) and oriented toward deterrence. During the Dutch colonial period, the purpose of the death penalty in Indonesia can be seen in the forming the 1918 Criminal Code, which stated in the

12 Dwija Priyatno.(2018). Bunga Rampai Pembaharuan Hukum Pidana Indonesia, Bandung: Pustaka Reka Cipta, p.153.

13 Eva Achjani Zulfa, "Pergeseran Paradigma Pemidanaan di Indonesia" Jurnal Hukum dan Pembangunan Tahun ke-36, Nomor 3, 2006, p. 393.

14 Ibid.

15 Ibid.

16 Ibid.

17 Ibid, p. 398 
explanation that the reasons situated to the particular circumstances of Indonesia as a Dutch colony. The risk of disrupting law order in Indonesia is greater and more threatening than in the Netherlands. Indonesia's population is diverse, which is very likely to cause clashes and others. Meanwhile, the government and the police are incomplete. Based on these conditions, it is considered that the death penalty cannot be abolished as the most superior weapon of the government.

The philosophy of capital punishment at that time emphasized more on the frightening aspects or deterrent effect attached to the emergency authority. The conception of emergency authority to justify maintaining capital punishment has an unprincipled and weak basis. When is the need for emergency authority and when it can be removed this emergency authority is very problematic. As Sahetapy said, the logical consequence of linking capital punishment to this emergency authority is that by abolishing this emergency authority, capital punishment must also be nullified. along with the development.

The philosophy of the death penalty at that time emphasized more on the frightening aspects or deterrent effect attached to the emergency authority. The conception of emergency authority to justify maintaining the death penalty has an unprincipled and weak basis. The issue of when it required the emergency authority and when this emergency ended. As Sahetapy said, ${ }^{18}$ the logical consequence of associated the death penalty to the emergency authority is that by abolishing this emergency authority, capital punishment must be nullified as well. Along with the development of thought, the purpose of criminal charge in the Draft Penal Code is adhering to the neo-classical paradigm with several regulated characteristics. Those characteristics included the formulation of minimum and maximum crimes, recognizing principles or circumstances that alleviate punishment based on objective conditions, and consider the need for individual development of criminal offenders. The purpose of the death penalty has shifted in future criminal law reforms (Draft Criminal Code). It aimed more at the function of the death penalty, which focuses on prevention, crime by upholding legal norms and put it as a last resort to protect the public or protect the public. This reform is very closely related to the criminal justice system, which is a form of implementation of the intended purpose. It is also as a middle way to bridge the abolitionist group and the retentionist group. The death penalty also oriented to the idea that the identification of criminal objectives based on a balance of two main targets, namely "community protection," including victims of crime and "protection/ development for individual perpetrators of criminal acts." From the point of view focuses more on the protection of the interests of the community; it is reasonable for the government to maintain the type of severe sanctions, namely the death penalty and life imprisonment. However, the death penalty not included in the main criminal charge, but rather is placed separately as a special or exceptional criminal offense. The main consideration shifted the position of the death penalty based on the idea of the objective of punishment and the purpose of the establishment or use of criminal law as a means of "criminal policy" and "social policy," then the death penalty, not the main tool for regulating, disciplining and improve society.

\section{CONCLUSSION}

The renewal of criminal law through the Draft Penal Code is a significant event, especially in the development of criminal law in Indonesia. The death penalty in the Penal Code no longer a primary crime but separates as an individual provision from the primary criminal provisions. The Draft Criminal Code bases on Neo-Classical school of thought, which maintains a balance

18 J.E. Sahetapy.(1982). Suatu Studi Khusus Mengenai Ancaman Pidana Mati Terhadap Pembunuhan Berencana, Ja karta: Rajawali, p.49.

62 Titin Nurfatlah, Amiruddin \& Ufran | The Shift Paradigm of the Death Penalty... 
between objective factors (actions / outward) and subjective factors (people/inner/ inner attitudes). This school of thought developed in the 19th Century, which focused its attention not only on acts or criminal acts that occurred, but also on individual aspects of the criminal conduct (Daad-dader Strafrecht). Another fundamental thought that influences the drafting of the New Criminal Code is the development of knowledge about victimology, which places significant attention on the fair treatment of victims of crime and abuse of power. Spirit of renewing criminal law in Indonesia also based on the value of the Pancasila as the philosophy of the Indonesian Nation. The penal system, as prepared in the draft Criminal Code motivated by a variety of basic ideas or principles, one of which is the idea of monodualistic balance between the interests of the public (general) and individual interests. Some provisions do not exist or never regulated in the Dutch Legacy Criminal Code (WvS) that are still in force today, one of which is the conditional death penalty.

\section{Bibliography}

Amiruddin dan Zainal Asikin.(2016). Pengantar Metode Penelitian Hukum, Cet. 6, Jakarta: PT. Rajagrafindo Persada.

Andi Hamzah. (2003). Pengkajian Hukuman Mati di Indonesia, Jakarta: BPHN Departemen Hukum dan HAM.

Barda Nawawi Arief. (2004). "Pokok-Pokok Pemikiran (Ide Dasar) Asas-Asas Hukum Pidana Nasional," Makalah dalam Seminar Nasional tentang Asas-Asas Hukum Pidana Nasional, Diselenggarakan oleh BPHN Departemen Kehakiman dan HAM RI Jakarta bekerjasama dengan Fakultas Hukum UNDIP Semarang, 26-27 April 2004.

Barda Nawawi Arief. (2008). Bunga Rampai Kebijakan Hukum Pidana:Perkembangan Penyusunan Konsep KUHP Baru.Cet.5. Jakarta: Prenadamedia Group.

Barda Nawawi Arief. (2010). Kebiajakan Hukum Pidana . Jakarta :Kencana Prenada Media Group.

David Garland. (2010). Peculiar Institution (America's Death Penalty In An Age Of Abolition). Cambridge, Massachusetts:The Belknap Press Of Harvard University Press.

Dwija Priyatno. (2018). Bunga Rampai Pembaharuan Hukum Pidana Indonesia, Bandung:cPustaka Reka Cipta.

Eva Achjani Zulfa, "Pergeseran Paradigma Pemidanaan di Indonesia", Jurnal Hukum dan Pembangunan Tahun ke-36, Nomor 3 , 2006.

J.E. Sahetapy.(1982). Suatu Studi Khusus Mengenai Ancaman Pidana Mati Terhadap Pembunuhan Berencana, Jakarta: Rajawali.

Sajipto Raharjo. (2010). Sosiologi Hukum, Yogyakarta: Genta Publishing.

Soemitro, Rinny Hanitijo. (1990). Metodologi Penenlitian Hukum dan Jurimetri. Jakarta:Ghalia Indonesia.

Slamet Mulyana.http://www.kerajaannusantara.com/id/kutai-kartanegara/hukum/, diunduh pada tanggal 11 Maret 2020. 